Peer-Reviewed Article

ISSN: 2162-3104 Print/ ISSN: 2166-3750 Online

Volume 5, Issue 4 (2015), pp. 459-474

(C) Journal of International Students

http://jistudents.org/

\title{
Coming to America: Assessing the Patterns of Acculturation, Friendship Formation, and the Academic Experiences of International Students at a U.S. College
}

\author{
Pamela Leong, PhD \\ Salem State University (USA)
}

\begin{abstract}
Using interview data from 11 international students, this paper compares international students' experiences at a single American university, and the acculturation issues that they encountered. The students assessed their experiences at the university, both positive and negative, and discussed their perceptions of American ways of doing things. The findings suggest that, when compared to students from other countries, students from China face considerable more difficulties both academically and socially, given the formidable language and cultural barriers. These challenges remain regardless of whether the students self-segregate with co-nationals or associate primarily with Americans. While individual-level factors (e.g., language fluency and coping ability) affect the international students' lived experiences and perceived satisfaction level while studying in the United States, this paper argues that environmental factors (e.g., the culture and reception of the host society) may be more important in shaping the experiences of international students, whether for better or worse.
\end{abstract}

Keywords: international students, American colleges, acculturation, language and cultural barriers

In the 2012/2013 academic year, the number of international students in colleges and universities in the United States was at an all-time high, at 819,644. The top sending countries were China, India, and South Korea, which represented the countries of origin of nearly $50 \%$ of all international students in the United States (Institute of International Education, 2013).

The increased representation of international students in U.S. colleges and universities has proven to have significant effects. For one, the international students contribute positively to the U.S economy, to individual state economies, and to their host institution's economic health. The presence of international students also has social consequences, contributing to the cultural diversity of nation, state, and local areas. The international students' intellectual and creative contributions also are felt2 in American research and in developments in science and technology, and other disciplines. Finally, the international community in American colleges and universities has implications regarding global relationships, whether that is between nation-states, or global business and economic communities. For all of these reasons, it is important that we consider 
the experiences of international college students in the United States. This current study attempts to do just this, with a special focus on students from China, the top sending country.

\section{Literature Review}

Studies of international college students from Asia in American colleges vary in focus and scope. Li and Bray (2007) assessed push-pull factors that influence mainland Chinese students' decision to study abroad in Hong Kong and Macau. Other studies underscored the role of English fluency on international students' academic performance in American colleges (Light, Xu, \& Mossop, 1987; Spinks \& Yo, 1984).

The literatures that examine how international students adjust to their new social environment typically conclude that the factors that influence acculturation include: country of origin; English fluency; and social support (Nasirudeen, Josephine, Adeline, Seng, \& Ling, 2014; Yeh \& Inose, 2003). These factors may help explain the differences in experiences and overall satisfaction level among international students. Generally, students with familiarity and knowledge of the English language and with American ways of doing things were more prepared to handle both institutional and societal-wide demands and expectations. They also developed more friendships. European students, who have greater English fluency and familiarity with American customs, also face greater social support and higher satisfaction levels once in the United States, when compared to students from non-European countries (Yeh \& Inose, 2003).

Asian students, in contrast, experience more acculturative stress than their European counterparts, and the Asian students who socialize primarily with co-ethnics experience higher levels of acculturative stress (Poyrazli, Kavanaugh, Baker, \& Al-Timimi, 2004; Yan \& Berliner, 2013). In fact, Yan and Berliner concluded that life in the United States was not only not easy for the Chinese students, but that Chinese students faced considerable and multifaceted life stresses that included both personal concerns (e.g., job opportunities, visa problems, and dating issues) and sociocultural concerns (e.g., the experience of culture shock and difficulties adjusting to the host culture).

The stress associated with acculturation will affect international students' overall satisfaction in the host country. Sam's (2001) study revealed that international students in Norway on the whole reported overall life satisfaction, but that their life satisfaction levels varied depending on country of origin. Students from Europe and North America were more satisfied than students from Asian or Africa. In Sam's study, factors that affected international students' self-perceived life satisfaction levels included: number of friends, satisfaction with finances, perceived discrimination, and the adequacy of the information received prior to studying abroad. Interestingly, neither language proficiency nor having a host national friend affected life satisfaction significantly.

Al-Sharideh and Goe (1998) indirectly measured the satisfaction level of international college students by measuring international students' "personal adjustment," which they defined as "the maintenance or achievement of high self-esteem by an international student within the context of an American university (Al-Sharideh and Goe, 1998, p. 709). They explicitly assumed that international students who were able to "more extensively assimilate American culture and learn to effectively interact with Americans will be more successful in avoiding personal problems, meeting life needs, and fulfilling academic demands” (Al-Sharideh and Goe, 1998, p. 700)--outcomes that likely shape international students' perceived satisfaction of their study-abroad experiences in the United States. In Al-Sharideh and Goe's study, key to

September/October 2015 http://jistudents.org $\quad$ Volume 5 •Issue 4


international students' successful assimilation were their social ties--specifically, having ties to co-ethnics (people with a similar cultural background or nationality. In fact, the number of strong ties with co-ethnics was found to have the strongest relationship with self-esteem, but only to a certain degree. Beyond the threshold point of 32 people, additional co-ethnic ties became negatively associated with self-esteem (Al-Sharideh and Goe, 1998, p. 720).

Thus, having a very strong co-ethnic tie or having only co-ethnic ties exclusively does not buffer international students from problems associated with cultural adjustment. But no matter the size of their co-ethnic ties, international students cannot avoid interacting with Americans, both within and outside of the university context. Thus, Al Sharideh and Goe (1998) suggested that, independent of the strength and size of their co-ethnic ties, international students' self-esteem ability to develop strong ties with Americans will positively affect their self-esteem (p. 722).

Baba and Hosoda's (2014) more recent study also confirmed the importance of social support to international students' adjustment issues, finding a direct and positive relationship between social support and cross-cultural adjustment. Their findings, however, did not specify whether the form of social support was co-ethnic support or local support (support by the host members).

International students' satisfaction level also may be inferred through the level of racial or ethnic discrimination experienced. This area is one in which Lee and Rice (2007) explored when they examined the experiences of 24 international students from 15 countries who were studying at a research university in the American Southwest. The international students in their study encountered difficulties that went beyond mere assimilation challenges; there were brushes with inhospitable behaviors, cultural intolerance, and racial and ethnic confrontation.

While literatures that examine the experiences of international college students are welldocumented, many of the literatures focus on international students' experiences at large research universities. My study departs from this trend by examining the experiences of international students at a regional, teaching-intensive university. In addition, the current study provides a more holistic treatment of the full college experience; I assess not only the effects of language and cultural barriers on international students' academic success, but also compare the outcomes of other rites of passage for college students, including friendship formation and dating experiences. Lastly, the current study uses interview data, rather than survey data. The use of interview data allows for a deeper understanding of how the international students make sense of the new world around them, in ways that survey data disallow.

The main research question that organizes this study is: What factors facilitate or impede the academic and social experiences of international students at American colleges and universities, and do they vary by country of origin?

\section{Methods}

Data were collected at a single American university through face-to-face interviews. The interviews were semi-structured, face-to-face, and one-on-one. Each interview took approximately two hours and occurred on campus. The interviews were conducted in English. Participants were asked a series of open-ended questions about their background and about adjustment issues related to the college campus, the region, and the United States in general. Participants also were asked about their social relationships in the United States, and their perceptions of American culture. 
Table 1. Respondent Characteristics

\begin{tabular}{|c|c|c|c|c|c|}
\hline $\begin{array}{l}\text { COUNTRY } \\
\text { OF ORIGIN }\end{array}$ & GENDER & AGE & $\begin{array}{c}\text { ACADEMIC } \\
\text { MAJOR }\end{array}$ & $\begin{array}{l}\text { LENGTH OF } \\
\text { STAY IN THE } \\
\text { U.S. }\end{array}$ & $\begin{array}{c}\text { LENGTH OF } \\
\text { STAY AT THE } \\
\text { HOST } \\
\text { INSTITUTION }\end{array}$ \\
\hline Afghanistan & male & 35 & ESL & $\begin{array}{l}2 \text { years, } 9 \\
\text { months }\end{array}$ & $\begin{array}{c}2 \text { years, } 5 \\
\text { months }\end{array}$ \\
\hline Cote d' Ivoire & male & 23 & economics & $\begin{array}{l}2 \text { years, } 11 \\
\text { months }\end{array}$ & $\begin{array}{c}2 \text { years, } 2 \\
\text { months }\end{array}$ \\
\hline Nepal & female & 25 & psychology & 5 years & 1.5 years \\
\hline Sweden & male & 22 & $\begin{array}{l}\text { international } \\
\text { business }\end{array}$ & $\begin{array}{c}1 \text { year, } 2 \\
\text { months }\end{array}$ & 1.5 months \\
\hline China & male \#1 & 20 & $\begin{array}{l}\text { business } \\
\text { management }\end{array}$ & 2 months & 2 months \\
\hline China & male \#2 & 21 & accounting & $\begin{array}{c}1 \text { year, } 2 \\
\text { months }\end{array}$ & 1 year, 2 months \\
\hline China & male \#3 & 21 & finance & $\begin{array}{c}1 \text { year, } 3 \\
\text { months }\end{array}$ & 1 year, 3 months \\
\hline China & male \#4 & 23 & athletic training & 1 year & 1 year \\
\hline China & male \#5 & 21 & $\begin{array}{l}\text { computer } \\
\text { science }\end{array}$ & 1 year & 1 year \\
\hline China & female \#1 & 20 & $\begin{array}{l}\text { international } \\
\text { business }\end{array}$ & 2 months & 2 months \\
\hline China & female \#2 & 20 & $\begin{array}{l}\text { international } \\
\text { business }\end{array}$ & 2 years & 2 years \\
\hline
\end{tabular}

\section{Sampling}

At the time of this study, the interview respondents were enrolled full-time at an eastcoast, regional university that is located in a small city on the eastern seaboard of the United States. Less than a quarter of the city's population is non-White. This teaching-intensive university is a medium-sized, four-year university with some master's level programs. As of 2013, 206 (2.7\%) of the undergraduates are international students. The university serves many disadvantaged students, including low-income students and first-generation students.

As a monolingual sociology faculty who is an American-born female of Chinese (Taiwanese and Malaysian) descent, I originally recruited international students at the university through the assistance of the director and staff at the Center for International Education (CIE). Faculty colleagues also helped in the recruitment. Additional recruitment occurred through the posting of flyers around campus. Finally, upon the completion of an interview, a respondent might refer a fellow international student to me. Hence, the sampling strategy used a combination of convenience, snowball, and purposive sampling. Chinese students were purposefully oversampled.

With the permission of the respondents, I audiotaped the interviews. I transcribed verbatim all interviews, and assessed for patterns across the interview data, both within national groups and across national groups. The study received approval from the Institutional Review 
Board. To protect the identities of the respondents, in this paper I refer to the respondents only by their nationality, sex, and age.

\section{Sample Characteristics}

I interviewed 11 international students during the fall 2013 semester. The interviews lasted, on average, two hours each. All students were undergraduate students. Of the 11 international students that I interviewed, seven were from China, one from Sweden, one from Nepal, one from Cote d'Ivoire, and one from Afghanistan. Eight interview respondents were male, and three were female. The respondents' ages ranged from 20 to 35, with a mean age of 22.8 years. Table 1 provides a summary of the respondent characteristics.

\section{Student Criteria for Selecting the American College}

For two of the 11 international students, affordability was the deciding factor in selecting Regional State University (this is a pseudonym, abbreviated as RSU). The Afghani male had started out at a college in a southern state, but the English-as-a-Second-Language classes there were too expensive. He searched on the internet and found that RSU was among the least costly. For the Nepalese female, foremost, too, was affordability, which is why she chose RSU over other colleges in the area. But she also chose RSU because she felt the school was gaining in popularity. Third, she already had friends at RSU, and these friends referred her to the university.

The Ivorian male selected RSU because of his family connection at the school. He had a cousin who was attending RSU at the time he applied. This cousin helped him with his application materials and later helped him negotiate the campus, local life, and American society in general.

The Swedish male was already a student at a community college in upstate New York when a RSU athletic coach recruited him. In addition, the Swedish student had friends at an area university who had described the area to him. The area surrounding RSU "sounded beautiful," so he felt it was "right" to attend RSU.

All of the Chinese students I interviewed were in a "one-to-one program," which is a partnership between certain American colleges and certain Chinese colleges. The Chinese students begin their first year of college in China, then spend the next two years in an American college, then complete their fourth and final year back at their Chinese college. The students are able to select from a list of American colleges to attend, including RSU.

For the Chinese students I interviewed, the location of the college usually was the deciding factor. All of the Chinese students I interviewed selected RSU foremost because of its proximity to a known metropolitan area. Chinese male \#5 specifically wanted to be near a big city, but also wanted to be near New York City, and near the ocean. The city in which RSU is located satisfied these three requirements, leading to his selection of the campus.

Before Chinese male \#2 came to the United States, he was not very acquainted with the expansive choices of American colleges, but the presence of well-known, elite universities in the region suggested that attending college in this area of the United States was a good choice in terms of quality education. Chinese male \#2 therefore selected RSU because of its proximity to a metropolitan area and because of the reputation of the area colleges and universities. 


\section{Results}

\section{Language Barriers Experienced}

A language barrier was the biggest challenge that the international students faced, leading to other adjustment issues. A lack of full fluency of American English undermined the students' ability to communicate with peers and others, occasionally leading to miscommunication and misunderstandings, as well as the inability to form friendships. The language barrier also affected some of the students' academic success.

As Chinese male \#2 put it: "When I came here, I could not understand what others were saying, and I could not say something I want clearly. Like others could not understand what I was saying. That's a big challenge for me when I just came here.” Chinese male \#4 concurred, noting that when he talks to Americans, "I talk like a new baby." Chinese female \#1 indicated that her ability to study at RSU was hampered by a language difference. As she explained, sometimes she tried to study with her American peers, but was unable to explain her thoughts cogently. This inability to articulate her thoughts into understandable American English also affected her ability to make friends. Similarly, language was the biggest challenge for the Ivorian male, who noted that sometimes he did not fully understand what Americans were saying; meanwhile, some Americans also were unable to understand his line of thought, but pretended to understand him by smiling and nodding.

The language barrier also may affect international students' academic success and everyday communication. For Chinese male \#1, the language barrier meant needing to put in double time to complete his homework assignments. For other Chinese students, the use of a translation dictionary was necessitated at times, while on other occasions, they sought the help of their friends, both co-national friends and American friends. As Chinese male \#4 put it, because of the language barrier, he became less social and more socially isolated, which affected his confidence level in terms of communicating and interacting with Americans.

\section{Cultural Differences and Cultural Misunderstandings}

Chinese male \#2 described an event involving a cultural misunderstanding. His roommate had baked a lot of pizza and Chinese male \#2 had helped himself to a piece, because he assumed the food was to be shared, as was customary in China, and also because of the sheer quantity of pizza available. His roommate, however, reprimanded him and told him that "You should ask [first].” Realizing his error, Chinese male \#2 was really embarrassed.

In other cases, Americans might misinterpret the behaviors of international students. Chinese female \#1 explained, for instance, that there were different connotations associated with hand-holding among girls and young women. In the U.S., she explained, girls holding hands might signify a lesbian relationship. In China, however, handholding among girls is common, indicating that two girls are good friends who enjoy spending time with each other. Hence, Chinese girls may be seen holding hands or linking arms but the relationship is purely platonic.

Food. Food represented a major cultural change for Chinese students in particular. Chinese students seemed to have more difficulty getting used to American food and especially American junk food. Furthermore, the Chinese food that is available in the area surrounding campus, or even in city, tend not to be authentically Chinese; rather, Chinese food in the U.S., according to the Chinese students, tend to be Americanized: The dishes are loaded with sugar, salt, and preservatives. This point was mentioned by Chinese males \#1, \#2, and \#5, Chinese

September/October $2015 \quad$ http://jistudents.org $\quad$ Volume $5 \bullet$ Issue 4


females \#1 and \#2. The Swedish male also observed the ubiquity of American fast food and the general unhealthy nature of American food.

Food was not an issue for some of the respondents, however. The Ivorian male, for instance, while yearning for food from his country of origin, noted that he was able to obtain most of the ingredients (or similar ingredients) he needed to prepare Ivorian meals, as most of the ingredients were readily available in mainstream American grocery stores. On occasions, though, the ingredients were not available in the mainstream grocery stores, which then required visits to specialized grocery stores.

Food also was not an issue for Chinese male \#3, who, in contrast to some of his conational counterparts, expressed his fondness for American food. He also appreciated how, in this part of the United States, cuisines from different cultures were so readily available, unlike in China, where "Chinese people only eat Chinese food.” His peer, Chinese male \#4, also enjoyed American fast food, at least initially. But then he confessed how he gained almost 15 pounds from the American diet.

Pedagogical Differences. There are noticeable differences in teaching methods and expectations across institutions within a country, and across nations. Chinese male \#2 suggested that, at RSU, students were required to take greater responsibility for their education, as they were required to work more independently. In contrast, at the Chinese colleges, professors and classmates regularly reminded students of assignments, due dates, and possible grade penalties. These reminders were largely facilitated because Chinese college students take the same courses with the same set of peers, who tend to keep each other on task. In contrast, at RSU and most other American colleges, the student constitution in each class may differ, so that students may see a different set of students (comprising both within and outside of one's major) in each class.

In addition, in China, course grades are dependent on students' performance on one or two exams only. In contrast, at RSU the course grade typically is not determined by a single exam, but multiple exams, homework assignments, and even participation and attendance. Such a difference in grading expectations was surprising to the Chinese students, who seemed to prefer RSU's method.

The Swedish male student felt that college education in the United States and Sweden was comparable, with some minor differences. One of the biggest differences, he stated, was that in Sweden, there are no homework assignments; instead, there are two major exams for each class, very much like the Chinese system. Hence, a student's course grade depends on his or her performance on those exams. And very much like the Chinese system, class attendance is not mandatory. All that is required is that students perform well on the exams.

The Swedish student, very much like some of the Chinese students, preferred the system at RSU, where a student's course grade was determined by various elements, and not just a single or even two exams. As the Swedish student put it:

I don't think you should put that pressure on a student. Think about if you have to take

five different classes. You have five mid-terms in one week. That's going to be kind of hard to remember all those parts, you know?

In terms of class size, the Swedish student noted that RSU classes were larger than classes in Sweden. The Chinese students in this study, in contrast, pointed out that classes in China were much larger, with up to 150 students or so in a class. 
Faculty-Student Relations. The Afghani male observed there was greater facultystudent communication both in class and outside of class at RSU. He further observed that students could email their professors anytime outside of class.

The Swedish male felt that American professors were more formal, compared to their Swedish counterparts. In Sweden, he explained, "You can say whatever you want." And according to his friends back home, the professors in Sweden were not like parents, but more like friends. Chinese male \#2, in contrast to the Swede, felt that American college professors were more like friends, when compared to Chinese college professors. As he described it, in the U.S., "You can talk about anything. You can call the professor's name and easily they don't mind, but in China, you will never call the professor's name. You can only call him or her 'Professor' or 'teacher." Chinese male \#2 felt that there was a difference in the respect accorded to the professors, with more respect given to Chinese professors.

Chinese male \#2 felt the difference in faculty-student relationships had much to do with the institutional culture. He observed the more informal relationships between faculty and students at RSU. In China, he stated that a professor simply lectures and "nothing else." In contrast, he felt that the professors at RSU engaged in small talk and would converse with students about non-academic topics, such as the latest sporting event, so discussions did not merely center around class materials.

Three of the Chinese male students believed that the professors in China were not as strict as American professors. Their perception was based on a comparison of the quantity of assignments: Very little homework was assigned in their colleges in China. Second, Chinese professors were not as likely as American professors to reprimand students when the students were playing around on their cell phones. For Chinese male \#3, American college professors also had more requirements, while for Chinese male \#4 it was the American professors' practice of taking class attendance daily that hinted to their strictness.

Differentials in Academic Resources. For the Afghani male, the most striking difference between the school systems in Afghanistan, Iran, and the United States had to do with the sheer disparity in resources, particularly access to up-to-date information and materials, which schools in Iran tend not to have. In addition, the Afghani student observed that a lot of the academic materials in both Afghanistan and Iran actually come from the United States or other western societies, but the materials were not often translated into Iranian or Afghani languages.

Iran poses a special challenge, according to the Afghani male, who described social problems as rampant in Iran and the political structure as "a dictator regime." As a result, in Iran, the origins and extent of societal problems such as poverty, violence, and drug abuse are concealed. Updated statistics and literatures about crime, for instance, are not issued. And when statistics are released, they are distorted statistics. The absence of accurate information, thus, poses a challenge to not just academics and students, but to the general public.

\section{Social Concerns}

The Roommate Situation. The Afghani male, Ivorian male, and Nepalese female always have lived off campus. The Swedish male and all the Chinese students live on campus, although second-year Chinese students typically choose to live off campus, in their own apartments. For the students who live off campus, the primary reason had to do with the cost. A second reason was that the dormitories at RSU close during holidays and breaks, which means that residential students would need to find temporary housing during that period, a requirement that proved to 
be either impossible or frustrating for the international students, who may not have family or close friends nearby.

During their first year at RSU, the Chinese students are required to live on campus, in dormitories. Roommates are assigned to them, rather than self-selected. Thus, in some cases, a Chinese student may be the single international student in a suite; in other cases, s/he may room with co-nationals (other Chinese students).

For the Chinese students who live on campus, there were special challenges, although not all the challenges were specific to their international student status. Personality and lifestyle differences among roommates proved to be a challenge. Chinese male \#4's roommates were all American. While he got along very well with his roommates, they regularly held parties in their suite at 2:00 or 3:00 in the morning. For Chinese male \#1, one roommate, also from China, had a reverse schedule in which he slept most of the day, rather than at night, and spent most of his time playing video games rather than studying.

The permissiveness of American culture also proved to be problematic at times for the Chinese students. In fact, some of the Chinese students I interviewed specifically pointed out the sexual permissiveness and overt sexual expressions that they observed among American college student, and among Americans in general. This included regularly bringing back to the dormitories sexual partners (e.g., girlfriends), which made at least one Chinese student uncomfortable. Although the Chinese student spoke to his American roommate about this issue, his roommate continued to bring his girlfriend to his room. In the end, the Chinese student avoided his own living quarters; instead, he would study in the hallways of his dormitory, and would return to his room only when it was time for bed.

Chinese female \#1 pointed out that one of her current roommates, a student from China, previously had all American roommates. As the sole international student (and the sole Chinese student) in a suite with all American women, the Chinese student felt very lonely. Although the American roommates and the Chinese roommate would converse, in the end the Chinese roommate never felt at ease in a sea of Americans.

In spite of some of these challenges, all of the Chinese students I interviewed seemed to have very good relationships with their roommates, even if there were personality and lifestyle differences. Chinese female \#2's roommates were all American, five in all. She enjoyed her experience and described her roommates as "awesome." One of her American roommates even invited her over to her family home for Thanksgiving. Chinese male \#5 enjoyed residential life so much that he decided to remain on campus in his second year. In his first year at RSU, he had four American roommates and a co-national roommate, and they were all "tight." The Swedish student also indicated that he had excellent relationships with all of his roommates, all of whom are American.

Friendship Formation. For the Swedish male, the biggest challenge was forming friendships in the absence of co-national peers. He described this as "probably the hardest part," but understood that friendship formation could take weeks or longer to establish. While the Swedish student expressed some initial challenges to friendship formation, forming friendships was especially troublesome for non-European students. In this study, the Chinese students expressed the greatest difficulty in forming friendships with American peers. But cultural differences also may hamper social relationships. Chinese male \#4 pointed out how, for instance, the individualistic orientation of Americans makes friendship formation more difficult. In China, because people engage in the same activities and the same line of work, they have 
shared interests and common things to talk about, which facilitate friendship formation. In the United States, however, Chinese male \#4 felt that people simply did their own thing. Chinese male \#4 further pointed out that Americans are more confident, but the over-confidence may mean that Americans may be less receptive to accepting new people, particularly foreigners.

Self-Segregation. Chinese male \#4 observed that many students from China selfsegregate. This is largely in part due to familiarity and comfort, as it is easier to communicate (especially for the women, Chinese male \#4 noted). On the other hand, the self-segregation is not entirely volitional. If there is a language barrier and a cultural barrier that make interactions between American students and Chinese students challenging, that will impede communication and friendship formation. Hence, some Chinese students may have little choice but to selfsegregate, as that may be the few means to maintain some sort of social network.

On the other hand, self-segregation may impede assimilation. Chinese female \#2 observed how some of the Chinese students would self-segregate, associating with only other Chinese co-nationals. This behavior was problematic, she pointed out, because "if you stop talking to foreign people, your English skill[s] will [diminish]."

Chinese male \#5 also observed the tendency for Chinese students to self-segregate. He pointed out the importance of interacting with members of the host country, however, but understood the difficulties of forming and sustaining friendships with Americans. As he stated:

In the beginning, because I didn't really want to hang out with all Chinese [students]. They just play [interact and communicate] with each other. They didn't want to go outside. They just want to live in their own [co-ethnic] circle. I didn't want to at first. [As a result,] I missed some [things], because I don’t hang out with Chinese friends, and my English is bad, so I couldn't meet any American friends. So at that time, I was so lonely.

Acknowledging that it is easier to self-segregate given that immigrants "understand each other more and we have the same topics to talk about and we are going through the same problems," the Nepalese female analyzed her social situation:

I really would like to make friends with people from all over the world. It's not that I don't want to. It's like how you get along with [them]? It's hard to get assimilated with them, not because they hate you or you hate them. Because you grew up in a different culture, you grew up in different circumstances.

Chinese male \#2 has many friends, both international friends and American friends, but primarily associates with fellow co-nationals. He expressed how difficult it was to make American friends.

In class, your classmates, you cannot even make friends, because you don't just have one the same class [with all of the same people]. They came before the class starts and leave right after class ends, so you don't even have a chance to talk to them, so it's very hard to make friends in class with your classmates. Like roommates, sometimes you have a lot of chance to talk, [so] you can make friends with them, unlike your classmates. 
Chinese male \#5 described associating primarily with Americans, but he also was close to some of his Chinese co-national peers. He indicated that he preferred to make friends with Americans, since "that's why I come here [to the U.S.]....I came here because I want to have some different experience[s] here.” It was Chinese male \#5's opinion that some of his conational peers ought to be more open to Americans. As he put it, while there initially might be some distance between Chinese students and American students, the Chinese students themselves have some responsibility to make an effort with Americans. Friendships can then form out of the connections. In other words, Chinese male \#5 was suggesting that foreigners need to make an effort with the hosts. He elaborated by stating:

I think Americans, they... when you are not friends, they treat you like an asshole, but once you become friends, you understand. So it's like every American, when you are not friends, they may be like don't talk to you and don't say hi to you, but once you become friends, you we can then play together or do something we like, but you have to make some conversation or communicate.

The Afghani student primarily associated with international students from his ESL classes but they are not co-nationals. The Ivorian student associated with fellow co-nationals, but also has a few American friends. The Nepalese student's friendships were with fellow conationals primarily, and the Swedes' friends were either Americans on or off campus, or fellow co-nationals outside of campus.

Among the seven Chinese students I interviewed, three were friends with fellow conationals primarily, although they may also have friendships with Americans and other international students. Two of the Chinese respondents associate primarily with Americans, and two associate with both Americans and co-nationals relatively equally.

Dating. The relationship status of the respondents varied. Chinese female \#1 has not dated since arriving in the United States, but she has only been in the United States for two months at the time of the interview. Chinese female \#2 and the Afghani male also have not dated since their arrival in the U.S. over two years ago. The Ivorian male has dated an American woman, although they are no longer together. The Nepalese female dated a fellow student at the American college from which she previously transferred. The Swedish male has a girlfriend back home, so avoids any romantic connections in the U.S. Chinese male \#1 also has a girlfriend back home. Chinese male \#2 has a co-national girlfriend who is a fellow student at the host institution. Chinese male \#3 also has a girlfriend at the same institution, and she also is a fellow co-National. Chinese male \#4 has not dated since coming to the U.S., although he has attempted to do so. Chinese male \#5 is in a noncommittal relationship with a fellow co-national at the host institution.

Three of the respondents, all Chinese males, indicated frustration with dating in a foreign country. Chinese male \#3 indicated that he has tried to date American women, but voiced how difficult it was for him to do so, because of the language barrier. He indicated that he is unable to fully express affection and endearments articulately to American women. Chinese male \#5 expressed a similar sentiment. He has a desire to date American women and to be in a committed relationship, but just has not taken the initiative of doing so. He cited language and cultural differences as major hurdles that have led to a diminishing of his confidence level. His low confidence level, shaped by his foreigner status, in turn, has made it difficult for him to 
communicate, and secure dates, with American women. Chinese male \#4, while acknowledging challenges with dating in the U.S., has yet to lose hope.

Chinese male \#4 observed that in dating relationships, Americans appear to be very direct, including in the expression of affections. In contrast, in China even the relatively benign gesture of hand holding may take a long time to achieve for a couple. Chinese male \#1 also observed that Americans are far more direct and open in terms of sexual expressions. He described instances in which American roommates would bring back into the dorms their dates, or significant others, where sexual activity would ensue.

\section{Financial Challenges}

While students who are able to study overseas tend to come from more affluent backgrounds, they, too, face financial challenges while studying abroad. In this study, there were four main sources of financial challenges: 1) high cost of living; 2) lack of job opportunities; 3) rising tuition; and 4) high textbook prices.

Some of the international students experienced a "sticker shock" when coming to the United States. Chinese male \#1 observed that the cost of living in the area in which the host institution was located was higher than what he was accustomed to in China; indeed, the area was part of one of the most expensive geographic areas in the United States, where even the price of very simple meals might be prohibitively expensive. The student from the Ivory Coast concurred with this assessment.

Linked to the high cost of living was a lack of job opportunities, a point underscored by the Afghani student in particular. After multiple attempts, the Afghani male remained unsuccessful in securing an on-campus job, although he acknowledged that this was in large part because of his international student status. He therefore was forced to obtain a low-paying offcampus job as a kitchen aide. At the prior school he attended in the southern part of the United States, however, the job prospects were more optimistic; he described receiving campus emails for job opportunities quite regularly. In contrast, at RSU, the Career Center kept providing him with assurances of "Okay, next month. Next month. Or next semester.” These empty promises went on for two years.

As job opportunities on campus continued to be sparse, the tuition seemed to increase exponentially. The Ivorian male emphasized that this sharp increase in tuition was definitely problematic. He pointed out the noticeable tuition increase that occurred in the short span of only two years. While he acknowledged that RSU was growing and that the school needed funding, he cautioned against any additional increases in student tuition, predicting that both the overall student enrollment and international student enrollment would decline because of the rising tuition.

But as the cost of tuition kept rising, so did the cost of textbooks. In fact, the Ivorian male also took issue of the costly textbooks. A single textbook for a music class cost him \$200. He felt the cost of textbooks was a waste of money, especially for textbooks used in classes that were outside of his major. The Swedish male was in agreement, noting that colleges in Sweden provide students with books, rather than requiring that students purchase textbooks out of pocket.

\section{Appreciating the Offerings}

In spite of encountering quite formidable challenges while studying in the United States, the international students offered praises when evaluating their experiences and host environment. The Afghani male, for one, appreciated the relatively low cost of RSU. "It's 
cheap," he said succinctly. The Nepalese female, however, was unsure what she liked best about her host institution. Chinese male \#5, on the other hand, could not rank what he liked the best, indicating that he liked "everything" about his study abroad.

Chinese female \#1 focused on environmental, rather than campus, elements, highlighting "the sky" as the best part about RSU. She described the sky as beautiful, and the "air is so clean and you can see a lot of stars at night. And the beach is very beautiful." The Swedish male also held the school location and surrounding area in high regard. He especially appreciated the proximity to the ocean and the overall beauty of the area.

Chinese male \#3 appreciated the quietness of the small city in which he temporarily was residing, and the friendly nature of the residents there. He observed that Americans often greeted strangers, even in the morning. Chinese male \#4 also acknowledged that it was the people that made the difference. In fact, it was his opinion that the best thing about RSU was "the people." Although he acknowledged that difficulties could arise, for the most part even these difficulties were "not bad things." Chinese male \#4 found meeting new people and experiencing a new culture to be "most exciting."

When assessing the quality of their education, the students I interviewed had high praises for RSU. Chinese male \#1 liked his professors, whom he described as "very patient." He also appreciated the small class size at RSU. Chinese male \#2 enjoyed the freedom of class selections, noting that students could select classes based on who the professors were, and whether their friends were also taking the class. In addition, students could take classes based on time of day, which meant that those students who tend to sleep in late could choose late morning or afternoon classes. Finally, Chinese male \#2 also appreciated the amenities that were offered to the students. This includes the use of the campus gym and the swimming pool.

The Ivorian male had high praises for the opportunities, resources, and overall education he has received at RSU. The Swedish male liked his professors and enjoyed life on campus. In fact, he stated that RSU "feels like home basically for me." Chinese female \#2 seemed to concur with these sentiments when she expressed her liking for "the people" at RSU. Her roommates have been especially good to her, and her professors have offered their help.

The students I interviewed also expressed their gratitude to the staff at the Center for International Education for helping them negotiate a new campus, a new region, and a new country, and for providing much assistance with housing, academic issues, and social issues. A few of the interview respondents singled out the director, as well as specific staff at the center, while other respondents expressed appreciation to the "seniors," or the second-year students in the one-to-one program.

\section{Discussion}

Cultural adjustment is a complex process. Certainly, individual-level factors such as language fluency and coping ability affect international students' lived experiences and satisfaction levels in their host environment. But arguably even more important are the culture and reception level of the host institution, host region, and host nation. That is to say, the level and quality of emotional, material, informational, and social support provided by the host institution, as well as by members of the local area and host nation, greatly facilitate, or else impede, international students’ adjustment and outcomes (Ramsay, Jones, \& Barker, 2007).

All international students, regardless of country of origin, experience a disorientation (or "culture shock") upon their arrival to the United States, whether in terms of language, food, 
customs, weather and climate, or something else. Within the academic institution, there is a further disorientation, as international students experience new teaching and learning styles, new disciplines and content areas, and as they socialize with American classmates (Kumi-Yeboah, 2014). East Asian students, however, have an especially difficult time adjusting to both academic life in American colleges, and to social life, given the pronounced language and cultural barriers. This is because East Asian culture and language are far more dissimilar from American culture and the English language than the cultures and languages of Europeans, South Americans, Africans, and South Asians.

In this study, Chinese students reported that they may not participate in class, instead opting for silence, because of their embarrassment associated with their limited English fluency. Unable to speak English fluently, Chinese students may become isolated, both individually and as a group. Unable to speak to Americans and other English-speaking individuals, Chinese students may self-segregate, but this separation may lead to feelings of loneliness and anxiety. The lack of English fluency, further, may lead to discrimination by members of the host country.

In addition to the language barriers, the cultural differences between American culture and the culture of the student's country of origin are especially pronounced for East Asian students. The much greater permissiveness in American culture, for instance, is both a source of freedom and a challenge for East Asian students, particularly with respect to sexual expressions and overt sexual displays. Cultural orientations and values also sharply differ for East Asian students in the United States. The United States stresses individualism and individualistic pursuits. In contrast, in China and many other East Asian nations, collectivism is prioritized. Such a difference may be overwhelming, if not unsettling, to Chinese students seeking an education in the U.S.

While language fluency and individual coping mechanisms shape international students' lived experiences in the host environment, environmental factors seem to play larger roles. In particular, the host institution's and host members' reception of the international students, and their respective levels of support, inevitably shape international students' experiences. Specifically, supportive social interactions with members of the host institution, host region, and host nation enable international students to feel more well-integrated into their new surroundings, leading to a sense of membership in their new communities.

Why does it matter that Chinese students have greater difficulty acculturating and assimilating? For one, there are psychological effects. Chinese students may feel inadequate, misunderstood, and dejected, leading to feelings of confusion, frustration, alienation, loneliness, anxiety, and depression. Indeed, Heikinheimo and Shute (1986) found that Chinese students experienced poorer mental and physical health when compared to other international students, and that Chinese students tended to interact less with students of the host country than other international students.

It also makes sense to keep international students happy, as the host institution, state, and host country benefit from their presence. International students contribute to the U.S. economy, the state economies, and the financial health of the academic institution in which they enroll; indeed, international students are a major source of revenue for various programs' survival in many colleges and universities (Hegarty, 2014). They also greatly contribute to the cultural diversity of their academic institution and local region.

International students also are important because when they return to their country of origin, they become sources of good will for the United States (Hegarty, 2014). This good will promotes more cooperative relationships between the United States and China, for instance. The

September/October 2015 http://jistudents.org $\quad$ Volume $5 \bullet$ Issue 4


international exchange program, hence, is very beneficial to the U.S. both economically and politically.

This study included interviews of only 11 international students, and they all are enrolled at a single university. Given the small sample size, findings from this study are not generalizable. Nonetheless, findings from this study may shed light on the specific challenges that international students encounter in American colleges, and may provide guidance on how institutions of higher learning might help better facilitate international students' entry into, and overall experience, at their host institution.

\section{Recommendations}

Because of the cultural differences that exist between students from the United States and those from China, it is crucial that American institutions of higher learning develop better ways to help these students avoid communication difficulties, and help foster more positive and cooperative relationships between individuals from two vastly different cultures. So how might institutions of higher learning such as Regional State University better address international students' needs, especially those from China and other East Asian countries?

It appears that Regional State University already practices all of the above and, according to the respondent narratives, has done quite well. But some of the respondent narratives seem to suggest there might be a bit more balance in terms of the roommate situation. On the one hand, being the sole Chinese student among a suite of American students may be discomforting. On the other hand, housing with students who are all co-nationals may impede acculturation into American society. This might be one area in which Regional State University can step in and remedy.

But there is a burden on the international students themselves. The individual students themselves must also contribute to the acculturation process. Immersing oneself in the host culture and spending more time with American peers can help Chinese students learn the English language quicker and become better acquainted with American ways of doing things.

Finally, there also should be some burden on members of the host country--here, fellow American students--who ought to extend a welcoming hand to international students, teach them about American ways of doing things, and also learn about the traditions and practices of international students. In other words, the learning process should not be one-sided; it should be somewhat reciprocal.

\section{REFERENCES}

Al-Sharideh, K. A., \& Goe, W. R. (1998). Ethnic communities within the university: An examination of factors influencing the personal adjustment of international students. Research in Higher Education, 39(6), 699-725.

Baba, Y., \& Hosoda, M. (2014). Home away home: Better understanding of the role of social support in predicting cross-cultural adjustment among international students. College Student Journal, 48(1), 1-15.

Heikinheimo, P. S., \& Shute, J. C. M. (1986). The adaptation of foreign students: Student views and institutional implications. Journal of College Student Personnel, 27(5), 399-406.

Hegarty, N. (2014). Where we are now - The presence and importance of international students to universities in the United States. Journal of International Students, 4(3), 223-235. 
Institute of International Education. (2013). Open doors 2013: International students in the United States and study abroad by American students are at all-time high [press release]. Retrieved from http://www.iie.org/en/Who-We-Are/News-and-Events/PressCenter/Press-Releases/2013/2013-11-11-Open-Doors-Data

Kumi-Yeboah, A. (2014). Transformative learning experiences of international graduate students from Africa. Journal of International Students, 4(2), 109-125.

Lee, J. J., \& Rice, C. (2007). Welcome to America? International student perceptions of discrimination. Higher Education, 53(3), 381-409.

Li, M., \& Bray, M. (2007). Cross-border flows of students for higher education: Push-pull factors and motivations of mainland Chinese students in Hong Kong and Macau. Higher Education, 53(6), 791-818.

Light, R.L., Xu, M., \& Mossop, J. (1987). English proficiency and academic performance of international students. TESOL Quarterly, 21(2), 251-261.

Nasirudeen, A. M. A., Josephine, K.W.N, Adeline, L. L .C., Seng, L. L., \& Ling, H. A. (2014). Acculturative stress among Asian international students in Singapore. Journal of International Students, 4(4), 363-373.

Poyrazli, S., Kavanaugh, P. R., Baker, A., \& Al-Timimi, N. (2004). Social support and demographic correlates of acculturative stress in international students. Journal of College Counseling, 7(1), 73-82.

Ramsay, S., Jones., E., \& Barker, M. (2007). Relationship between adjustment and support types: Young and mature-aged local and international first year university students. Higher Education, 54(2), 247-265.

Sam, D. L. (2001). Satisfaction with life among international studies: An exploratory study. Social Indicators Research, 53(3), 315-337.

Spinks, J. A., \& Ho, D. Y. F. (1984). Chinese students at an English-language university. Higher Education, 13(6), 657-674.

Yan, K., \& Berliner, D. C. (2013). Chinese international students’ personal and sociocultural stressors in the United States. Journal of College Student Development, 54(1), 62-84.

Yeh, C. J., \& Inose, M. (2003). International students' reported English fluency, social support satisfaction, and social connectedness as predictors of acculturative stress. Counseling Psychology Quarterly, 16(1), 15-28.

\section{AUTHOR}

PAMELA LEONG, Ph.D. is an assistant professor of sociology at Salem State University in Salem, Massachusetts, USA. Her research interests are varied, but her current scholarship focuses on American culture and inequalities in higher education. Email: pleong@salemstate.edu 